\title{
Boar taint related compounds: Androstenone/skatole/other substances Øystein Andresen*
}

Address: Norwegian School of Veterinary Science, Oslo, Norway

* Corresponding author

from Prevention of Boar Taint in Pig Production: The 19th Symposium of the Nordic Committee for Veterinary Scientific Cooperation Gardermoen, Norway. 21-22 November 2005

Published: 7 August 2006

Acta Veterinaria Scandinavica 2006, 48(SuppI I):S5 doi:I0.II86/I75I-0I47-48-SI-S5

C 2006 Andresen.; licensee BioMed Central Ltd.

\section{Introduction}

Two substances are the main contributors to boar taint in pork from entire male pigs i.e. the steroid androstenone (5 $\alpha$-androst-16-ene-3-one) [1] and skatole (3-methylindole) [2,3]. The relative contribution of these substances to boar taint varies in different studies. Other substances may also contribute to a minor degree and a range of substances with an off-odour/off-flavour has been identified in boar fat. Among these indole and other 16androstene steroids may be of some significance $[4,5]$.

In fat samples with low levels of androstenone and skatole, but which nevertheless had been classified as tainted, Angels Rius et al [6] identified aldehydes and short chain fatty acids as the main classes of substances related to offflavour. However, only a few substances were found in significantly higher concentrations in tainted compared to untainted samples. Styrene and 1,4 dichlorobenzene, whose presence may be due to contamination, showed a high concentration in tainted samples. Rius Solé and Regueiro [7] identified 4-phenyl-3-buten-2-one in samples of boar fat and reported that the presence of this compound in samples low in androstenone and skatole, could promote the perception of these substances.

\section{Androstenone}

Androstenone is produced in the testes. In plasma it is found in free form and in a sulfoconjugated form. Recently is has been found that around $70 \%$ of androstenone in plasma is in form of sulfoconjugated androstenone [8].
The secretory pattern of androstenone follows in general the secretory pattern of testosterone, although the biosynthesis of the two steroids follows different pathways. The ratio between testosterone levels and androstenone levels in plasma varies. Often the level of free androstenone in plasma is reported to exceed the level of testosterone. In plasma the level of free androstenone varies from a few ng and up to at least $40-60 \mathrm{ng}$ per $\mathrm{ml}$.

\section{The odour of $5 \alpha$-androstenone}

Olfaction in humans with reference to odorous 16androstenes, has been reviewed by Gower and Ruparelia [9]. The smell is often described as urinelike. It is well known that the ability to detect the smell of $5 \alpha$-androstenone varies. The results of an extensive survey were published by Gilbert and Wysocki in 1987 [10]. In Europe (UK not included) $24.1 \%$ of the female participants of the study and $15.8 \%$ of the males were unable to detect the smell of androstenone. However it has also been shown that the ability to perceive androstenone can be induced in a proportion of people with odour blindness or specific anosmia to androstenone. The participants of the study sniffed androstenone 3 minutes, 3 times a day for 6 weeks. In 10 out of 20 individuals that were anosmic to androstenone, the ability to perceive androstenone were induced [11]. The authors suggest a mechanism where olfactory neurons with specific receptors for androstenone undergo clonal expansion or selection of lineages with more receptors or receptors of higher affinity, much in the manner of lymphocytes responding to antigenic stimulation. 


\section{Physiology of $5 \alpha$-androstenone}

The well known physiological effect of androstenone and other 16-androstenes, is to act as pheromones and stimulate reproductive functions in the female pig. They are secreted into saliva in the submaxillary salivary glands. Submaxillary salivary glands from pigs contain a protein; pheromaxein, which binds 16-androstene steroids. The primary function of pheromaxein is the solubilization and transportation of pheromones in saliva. An effect on female pigs directly from 16-androstenes released from the boar as well as an effect over time due to saliva deposited in the environment has been proposed [12]. The odour of 16-androstenes facilitates the expression of the standing response in oestrous sows. It has also been shown that the smell of $5 \alpha$-androstenone elicits oxytocin release in oestrous sows [13].

Androstenone has no androgenic effect as measured by the "Chicken comb test" [14]. Whether it has any effect on its own production/secretion through a feed-back on the production/secretion of GnRH and gonadotropins, appears to be unknown. An effect in the testes can not be ruled out: a specific binding of $5 \alpha$-androstenone to human testicular cytosolic fraction has been reported [15].

It has been shown that $5 \alpha$-androstenone reduces agnostic behaviour in newly regrouped pigs [16]. Androstenone has also been found to affect the metabolism of skatole in the liver [17].

\section{Fate of $5 \alpha$-androstenone in plasma and fat}

$5 \alpha$-androstenone is a very lipophilic molecule. The water solubility of $5 \alpha$-androstenone is only $230 \mu \mathrm{g} / \mathrm{l}$ at $25^{\circ} \mathrm{C}$ [18]. The steroid appears to be easily transferred from plasma to adipose tissue. It has been found that if the level of $5 \alpha$-androstenone in peripheral plasma exceeds about $15 \mathrm{ng} / \mathrm{ml}$, a heavy accumulation of androstenone in fat usually follows [19]. Sinclair et al [20] reported that peripheral plasma levels of androstenone below $15 \mathrm{ng} / \mathrm{ml}$ were associated with low androstenone concentrations in fat, while a wide range of androstenone concentrations can be found in fat in animals with plasma levels above this value.

The levels of androstenone in adipose tissue can be doubled within a day following stimulation of androstenone production by the testes by hCG injection [21]. However, when the concentration of androstenone in peripheral plasma decreases from high levels, the concentration in adipose tissue do also gradually decrease. Thus there appear to be a dynamic relationship between androstenone in plasma and adipose tissue, but the detailed regulation of the transfer of androstenone between plasma and adipose tissue has not been clarified. In many species sex steroids are partly bound to specific proteins as sex hormone binding globulin (SHBG) and to albumin. A binding/association of $5 \alpha$-androstenone to plasma proteins would affect the transfer of the steroid into adipose tissue. However, it has been reported that pigs lack a sex hormone binding globulin (SHBG) in plasma [22]. To what extent androstenone in pigs is bound or associated to other plasma proteins is unknown.

Claus [23] has reported the disappearance rate of androstenone from adipose tissue following castration. He found halflives from 7 days in young boars (weights in the range of 90 to $97 \mathrm{~kg}$ ) till 16-19 days in older boars (weights in the range of 240-250 kg). Bonneau et al [24] found half-lives from 4 to 14 days in 9 boars castrated at 175 days of age.

Androstenone is metabolised by the liver. Isolated pig liver microsomes reduce androstenone mainly to $\beta$ androstenol [25]. These authors found that the rate of androstenone metabolism in pig liver microsomes was determined by the level of expression of hepatic $3 \beta$ hydroxysteroid dehydrogenase. They observed a much lower rate of androstenone metabolism in liver microsomes from pigs from a breed with high androstenone levels (Meishan) compared with liver microsomes from pigs from a breed with low androstenone levels (Large White), indicating differential expression or activity of the enzyme catabolising androstenone in the two breeds.

Differences in production rate of androstenone may however, be more important for the differences in androstenone levels in adipose tissue between pigs than differences in the catabolism of the steroid in the liver. Babol et al. [26] found no significant relationship between the oxidative metabolism of androstenone in the liver and the levels of androstenone in fat. The results of a study by Bonneau and Terqui [27] have indicated a very high metabolic clearance rate (MCR) for plasma androstenone. In one boar they calculated a MCR of about 80000 liters per day. The high disappearance was mainly ascribed to transfer and storage of androstenone into adipose tissue and salivary glands. If the production rate for androstenone is high, the capacity of the liver to metabolise androstenone may be insufficient and androstenone will accumulate in adipose tissue.

\section{Levels of androstenone causing boar-taint}

Different levels of androstenone have been proposed as cut-off levels for sorting carcasses. Claus et al [28] and Rhodes [29] suggested levels of 0.5 and $1.0 \mu \mathrm{g}$ androstenone per $g$ fat as cut-off levels to sort out tainted meat, respectively. 


\section{Skatole}

Skatole (3-metyl-indole) is a breakdown product of tryptophan. It has a fecal-like odor. Unlike the smell of androstenone the vast majority of people are able to detect the smell of skatole. Skatole is produced in the colon by microbial activity. Lactobacillus sp. strain 11201 is considered as the organism producing skatole causing boar taint [30]. Both tryptophan from the diet and from cell debris from degradation of intestinal mucosa can be metabolised to skatole.

Skatole does also seem to be easily transferred from plasma to adipose tissue. Following daily i.m. injection of skatole to intact male pigs for 9 days at a dose corresponding to the upper physiologically occurring levels $(1 \mathrm{mg} /$ $\mathrm{kg}$ ), the mean level of skatole in adipose tissue rose from $0.02 \mu \mathrm{g} / \mathrm{g}$ fat to $0.41 \mu \mathrm{g} / \mathrm{g}$ fat [26].

\section{Levels of skatole causing boar taint}

The rejection level for skatole in fat varies. In Denmark $0.25 \mu \mathrm{g}$ per gram fat and in Norway $0.21 \mu \mathrm{g}$ per gram fat has been used. In Denmark it has been calculated that a level of $0.25 \mu \mathrm{g}$ skatole per gram fat corresponds to a level in plasma of $7.5 \mathrm{ng}$ per ml [31]. In Sweden Babol et al. [32] found that a level of skatole of $12.6 \mathrm{ng} / \mathrm{ml}$ plasma correspond to a level in fat of $0.2 \mu \mathrm{g}$ skatole equivalents per gram.

Skatole dose not appear to play any physiological role in the pig. While skatole is toxic for many ruminant species and causes acute bovine pulmonary edema and emphysema, skatole is not toxic for pigs [30].

\section{Metabolism of skatole}

In pigs skatole is absorbed by the intestinal mucosa into the portal vein and passes through the liver where it is efficiently metabolised. There seem to be no differences between skatole production in the gut between male and female pigs [33]. The half life for skatole in plasma is approximately 60 minutes [34]. It has been demonstrated that the liver has a potential and a capacity to extract skatole from blood in quantities that greatly exceed what is found under physiological conditions [31]. In some boars a proportion of skatole, nevertheless passes the liver without being metabolised and accumulates in adipose tissue. The reason must be related to testicular activity and especially the action of sex steroids, androstenone included. Hepatic cytochrome P4502E1 (CYP2E1) is a main hepatic enzyme in the metabolism of skatole $[35,36]$. Doran et al. [17] found that skatole induced CYP2E1 protein expression while androstenone antagonised this effect in isolated hepatocytes. Thus high concentrations of androstenone might prevent CYP2E1 induction by the substrate skatole. The effect will be a reduced metabolism of skatole and accumulation in adipose tissue. The effect of androstenone may be that the steroid binds to a transcripton factor (COUP-TF1) and interferes with its binding to DNA [37]. It has been found that the level of P4502E1 in hepatic microsomes do increase following castration [38], giving further support to an inhibiting effect of testicular steroids on the hepatic metabolism of skatole.

\section{References}

I. Patterson RLS: 5 $\alpha$-androst-I6-ene-3-one: Compound responsible for taint in boar fat. J Sci Food Agric 1968, 19:31-38.

2. Vold E: Fleischproduktionseigenschaften bei Ebern und Kastraten IV: Organoleptische und gaschromatographische Untersuchungen wasserdampfflüchtiger Stoffe des Rückenspeckes von Ebern. Meld Nor Landbrukshogsk 1970, 49:25.

3. Walstra $\mathrm{P}$, Marse $\mathrm{H}$ : Investigation into sex odour of entire male pigs. IVO-Report C-I 47 (Sept 1970):30.

4. García-Regueiro JA, Diaz I: Evaluation of the Contribution of Skatole, Indole, Androstenone and Androstenols to BoarTaint in Back Fat of Pigs by HPLC and Capillary Gas Chromatography (CGC). Meat Science 1989, 25:307-316.

5. Gibis M: Einfluss der Substanzen Indol und Skatol auf die Schweinefleischqualität. Dissertation, Fakultät Allgemeine und Angewandte Naturwissenschaften der Univärsität Hohenheim 1994:I8I.

6. Angels Rius M, Hortós M, Garcia-Regueiro JA: Influence of volatile compounds on the development of off-flavours in pig back fat samples classified with boar taint by a test panel. Meat Science 2005, 71:595-602.

7. Angels Rius Solé M, Garcia-Regueiro JA: Role of 4-Phenyl-3-buten2-one in Boar Taint: Identification of New Compounds Related to Sensorial Descriptors in Pig Fat. J Agric Chem 200I, 49:5303-5309.

8. Sinclair PA, Squires EJ: Testicular sulfoconjugation of the 16androstene steroids by hydroxysteroid sulfotransferase: Its effect on the concentration of $5 \alpha$-androstenone in plasma and fat of the mature domestic boar. J Anim Sci 2005, 83:358-365.

9. Gower DB, Ruparelia BA: Olfaction in humans with special reference to odorous 16-androstenes: their occurrence, perception and possible social, psychological and sexual impact. J Endocrin 1993, 137:167-187.

10. Gilbert AN, Wysocki CJ: The National Geographic smell survey results. National Geographic Magazine 1987, I72:5 I4-524.

II. Wysocki CJ, Dorries K, Beauchamp GK: Ability to perceive androstenone can be acquired by ostensibly anosmic people. Proc Natl Acad Sci USA 1989, 86:7976-7978.

12. Booth WD: Factors affecting the pheromone composition of voided boar saliva. J Reprod Fert I987, 81:427-431.

13. Mattioli M, Galeati G, Conte F, Seren E: Effect of $5 \alpha$-androst-16en-3-one on oxytocin release in oestrous sows. Theriogenology 1986, 25:399-403.

14. Claus R: Bestimmung von Testosteron und $5 \alpha$-androst-16-en3-on, einem Ebergeruchsstoff, bei Schweinen. Dissertation. Technische Hochschule München 1970:144.

15. Kwan TK, Kraevskaya MA, Makin HLJ, Trafford DJH, Gower DB: Use of Gas Chromatographic-Mass Spectrometric Techniques in Studies of Androst-16-ene and Androgen Biosynthesis in Human Testis; Cytosolic Specific Binding of $5 \alpha$ androst-16en-3-one. J Steroid Biochem Molec Biol 1997, 60:137-146.

16. McGlone JJ, Morrow JL: Reduction of pig agnostic behavior by androstenone. J Anim Sci 1988, 66:880-884.

17. Doran E, Whittington FM, Wood J, Mc Giwan JD: Cytochrome P450IIEI (CYP2EI) is induced by skatole and this induction is blocked by androstenone in isolated pig hepatocytes. Chem Biol Interact 2002, 140:81-92.

18. Amoore JE, Buttery RG: Partition coefficients and comparative olfactometry. Chemical Senses and Flavour 1978, 3:57-7I.

19. Andresen $\varnothing$ : Concentrations of fat and plasma $5 \alpha$-androstenone and plasma testosterone in boars selected for rate of body weight gain and thickness of back fat during growth, sexual maturation and after mating. J Reprod Fert 1976, 48:5I-59. 
20. Sinclair PA, Squires EJ, Raeside Jl: Early postnatal plasma concentrations of testicular steroid hormones, pubertal development, and carcass leanness as potential indicators of boar taint in market weight intact male pigs. J Anim Sci 200I, 279: $1868-1876$.

21. Malmfors B, Lundstrøm K, Hansson I, Gahne B: The Effect of HCG and LH-RH on 5 $\alpha$-Androstenone Levels in Plasma and Adipose Tissue of Boars. Swedish J Agric Res 1976, 6:73-79.

22. Cook B, Hunter RHF, Kelly ASL: Steroid-binding proteins in follicular fluid and peripheral plasma from pigs, cows and sheep. J Reprod Fert 1977, 5 I:65-71.

23. Claus R: Pheromone bei Säugetieren unter besonderer Berücksichtigung des Ebergeruchstoffes und seiner Beziehung zu anderen Hodensteroiden. Fortschritte in der Tierphysiologie und Tierernährung 1979:136.

24. Bonneau M, Meusy-Dessolle N, Léglise PC, Claus R: Relationship between fat and plasma androstenone and plasma testosterone in fatty and lean young boars following castration. Acta endocrin (Kbh) 1982, I01:129-133.

25. Doran E, Whittington FM, Wood J, Mc Giwan JD: Characterisation of androstenone metabolism in pig liver microsomes. Chem Biol Interact 2004, 147: 14I- I49.

26. Babol J, Squires El: Liver metabolic activities of intact male pigs injected with skatole. Can J Anim Sci 1999, 79:549-552.

27. Bonneau M, Terqui M: A note on the metabolism of $5 \alpha$-androst16-en-3-one in the young boar in vivo. Reprod Nutr Dévelop 1983, 23:899-905.

28. Claus R, Weiler U, Herzog A: Physiological Aspects of Androstenone and Skatole Formation in the Boar - A Review with Experimental Data. Meat Science 1994, 38:289-305.

29. Rhodes DN: Consumer testing of bacon from boar and gilt pigs. J Sci Fd Agric 1971, 22:485-490.

30. Deslandes B, Gariépy C, Houde A: Review of microbiological and biochemical effects of skatole on animal production. Livestock Prod Sci 200I, 7I:193-200.

31. Agergaard N, Laue A: Absortion of skatole to portal vein blood and liver turnover in entire male pigs using an in vivo animal model. In Skatole and boar taint Edited by: Jensen WK. Danish Meat Research Institute, Roskilde; 1998:77-95.

32. Babol J, Zamaratskaia G, Juneja RK, Lundstrøm K: The effect of age on the distribution of skatole and indole levels in entire male pigs in four breeds: Yorkshire, Landrace, Hampshire and Duroc. Meat Science 2004, 67:35I-358.

33. Agergaard N, Jensen BB: Microbial production of skatole in the digestive tract, absorption to portal vein blood and liver turnover in entire male pigs. In Abstract from 44th Annual Meeting of the EAAP Aarhus, Denmark; 1993:33I.

34. Agergaard N, Laue A: Absorption from the gastrointestinal tract and liver turnover of skatole. In Measurement and Prevention of Boar taint in Entire Male Pigs Edited by: Bonneau M. INRA, Paris; 1993:107-111.

35. Squires EJ, Lundstrøm K: Relationship Between Cytochrome P450IIEI in Liver and Levels of Skatole and Its Metabolites in Intact Male Pigs. J Anim Sci 1997, 75:2506-25II.

36. Babol J, Squires EJ, Lundstrøm K: Hepatic Metabolism of Skatole in Pigs by Cytochrome P4502EI. J Anim Sci 1998, 76:822-828.

37. Tambyrajah WS, Doran E, Wood JD, McGivan JD: The pig CYP2EI promoter is activated by COUP-TFI and HNF-I and is inhibited by androstenone. Archives of Biochemistry and Biophysics 2004, 43I:252-260.

38. Whittington FM, Nute GR, Hughes SI, McGivan JD, Lean IJ, Wood JD, Doran $\mathrm{E}$ : Relationships between skatole and androstenone accumulation, and cytochrome P4502E I expression in Meishan X Large White pigs. Meat Science 2004, 67:569-576.

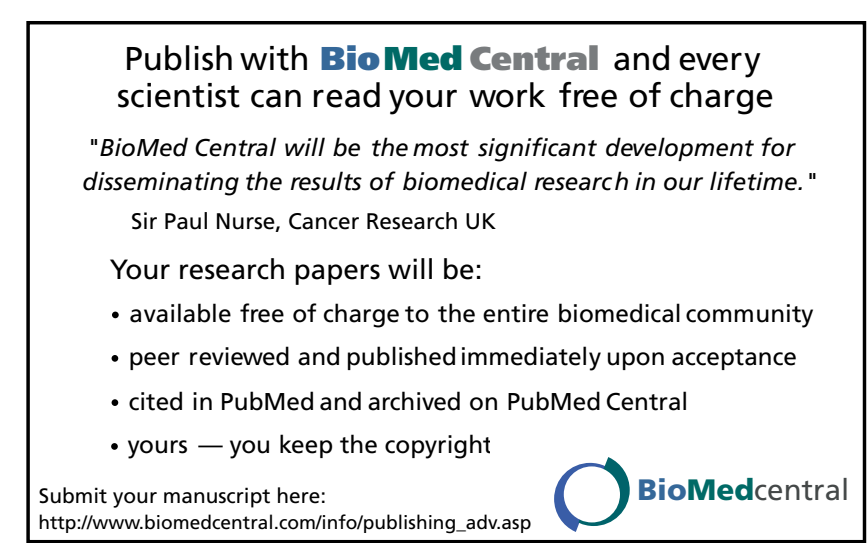

